Berlin, N. I., Neuberger, A. \& Scott, J. J. (1956). Biochem. J. 64, 90.

Brockman, P. E. \& Gray, C. H. (1953). Biochem. J. 54, 22.

Cole, S. (1933). Practical Physiological Chemistry, 9th ed., p. 327. Cambridge: Heffer.

Cookson, G. H. \& Rimington, C. (1954). Biochem. J. 57, 476.

Dresel, E. I. B. \& Falk, J. E. (1953). Nature, Lond., 172, 1185.

Falk, J. E., Dresel, E. I. B. \& Rimington, C. (1953). Nature, Lond., 172, 292.

Folin, O. \& Bell, R. (1917). J. biol. Chem. 29, 329.

Gibson, K. D., Neuberger, A. \& Scott, J.J.(1954). Biochem.J. 58, xli.

Gibson, K. D., Neuberger, A. \& Scott, J.J.(1955). Biochem. J. $61,618$.

Goldberg, A. \& Rimington, C. (1954). Lancet, 2, 172.

Granick, S. \& Vanden Schrieck, H. G. (1955). Proc. Soc. exp. Biol., N.Y., 88, 270.

Muir, H. M. \& Neuberger, A. (1949). Biochem. J. 45, 163.

Neuberger, A. \& Scott, J. J. (1953). Nature, Lond., 172, 1093.

Neuberger, A. \& Scott, J. J. (1954). J. chem. Soc. p. 1820.

Prunty, F. T. G. (1945). Biochem. J. 39, 446.

Ratner, S., Rittenberg, D., Keston, A. S. \& Schoenheimer, R. (1940). J. biol. Chem. 134, 655.

Ratner, S., Schoenheimer, R. \& Rittenberg, D. (1939). J. biol. Chem. 134, 653.

Ratner, S., Weissman, N. \& Schoenheimer, R. (1943). J. biol. Chem. 147, 549.

Schoenheimer, R. (1946). The Dynamic State of Body Constituents, 2nd ed., p. 51. Cambridge: Harvard University Press.
Schoenheimer, R., Ratner, S. \& Rittenberg, D. (1939a). J. biol. Chem. 127, 333.

Schoenheimer, R., Ratner, S. \& Rittenberg, D. (1939b). J. biol. Chem. 130, 703.

Scott, J. J. (1955). In The Biosynthesis of Porphyrins and Porphyrin Metabolism, Ciba Foundation Symp., p. 43. London: Churchill.

Shemin, D. (1955). In The Biosynthesis of Porphyrins and Porphyrin Metabolism, Ciba Foundation Symp., p. 4. London: Churchill.

Shemin, D., Abramsky, T. \& Russell, C. S. (1954). J. Amer. chem. Soc. 76, 1204.

Shemin, D., Gatt, S., Schmid, R. \& Weliky, I. (1955). Fed. Proc. 14, 279.

Shemin, D. \& Russell, C. S. (1953). J. Amer. chem. Soc. 75, 4873.

Shemin, D., Russell, C. S. \& Abramsky, T. (1955). J. biol. Chem. 215, 613.

Shuster, L. (1956). Biochem. J. 64, 101.

Sprinson, D. B. \& Rittenberg, D. (1949). J. biol. Chem. 180, 707.

Stetten, D. (1942). J. biol. Chem. 144, 501.

Van Slyke, D. D. (1915). J. biol. Chem. 22, 281.

Waelsch, H. \& Rittenberg, D. (1942). J. biol. Chem. 144, 53.

Waldenström, J. \& Vahlquist, B. (1939). Hoppe-Seyl. Z. $260,189$.

Weissman, N. \& Schoenheimer, R. (1941). J.biol.Chem.140, 779.

Wu, H. (1950). J. gen. Physiol. 34, 403.

Wu, H. \& Rittenberg, D. (1949). J. biol. Chem. 179, 847.

\title{
The Metabolism of $\boldsymbol{\delta}$-Aminolaevulic Acid
}

\section{NORMAL PATHWAYS, STUDIED WITH THE AID OF ${ }^{14} \mathrm{C}$}

\author{
By N. I. BERLIN,* A. NEUBERGER $\dagger$ AND J. J. SCOTT $\dagger$ \\ National Institute for Medical Research, Mill Hill, London, N.W. 7
}

(Received 4 January 1956)

In the preceding paper (Berlin, Neuberger \& Scott, 1956) are described the results of investigations of the metabolism of $\delta$-aminolaevulic acid (ALA) by administration of this compound to rats and to humans, and by studying the fate of the nitrogen of [ ${ }^{15}$ N]ALA in rats. It was shown that a large proportion of the ALA was rapidly excreted as such, together with a small amount of porphobilinogen (PBG). The incorporation of isotope into haem was lower than expected, being less than that from an equivalent dose of $\left.\left[{ }^{15} \mathrm{~N}\right] \mathrm{g}\right] \mathrm{ycine}$.

* Special Research Fellow, National Heart Institute, U.S. Public Health Service. Present address: Lieut.-Com. N.I. Berlin, U.S.N., 775 North Van Dorn Street, Alexandria, Virginia, U.S.A.

$\uparrow$ Present address: Department of Chemical Pathology, St Mary's Hospital Medical School, St Mary's Hospital, London, W. 2.
In this paper is described a more detailed investigation into the fate of administered ALA. Because of the greater dilution detectable, and because it affords information about other parts of the molecule, [1:4-14 $\left.\mathrm{C}_{2}\right]$ ALA was employed. The labelling was thus in the positions corresponding to the carboxyl carbon atoms of succinic acid, from which ALA is believed to be derived biologically.

The object of those experiments in which rats were used was twofold. It was desired to obtain data comparable with those resulting from our experiments with $\left[{ }^{15} \mathrm{~N}\right] \mathrm{ALA}$. It was also necessary to study the distribution of radioactivity from $\left[1: 4-{ }^{14} \mathrm{C}_{2}\right] A L A$ before administering it to a human subject.

There have already appeared preliminary accounts of parts of this work in which $\left[1: 4-{ }^{14} \mathrm{C}_{2}\right] \mathrm{ALA}$ was administered to rats and to a human subject 
(Berlin, Neuberger \& Scott, 1954; Berlin, Gray, Neuberger \& Scott, 1954; Scott, 1955) and to cockerels (Neuberger, 1955).

\section{EXPERIMENTAL}

\section{Preparation and isolation of compounds}

${ }^{14} \mathrm{C}-$ Succinic acid. $\left[1: 4-{ }^{14} \mathrm{C}_{2}\right]$ Succinic acid (Radiochemical Centre, Amersham Bucks.), after dilution with nonisotopic succinic acid, contained $32 \cdot 0 \mu \mathrm{c} / \mathrm{m}$-mole.

$\delta$-Aminolaevulic acid. $\left[1: 4-{ }^{14} \mathrm{C}_{2}\right]$ ALA was prepared by the method of Neuberger \& Scott (1954), starting with [1:4-14 $\left.\mathrm{C}_{2}\right]$ succinic acid (Radiochemical Centre, Amersham, Bucks). The isotopic succinic acid was cyclized to the anhydride, in $94 \%$ yield, by refluxing with an excess of freshly distilled acetyl chloride. After evaporation to dryness in vacuo from a boiling-water bath, the crude anhydride was used for the subsequent reaction without purification. The crude hydrochloride of $\left[1: 4-{ }^{14} \mathrm{C}_{2}\right] \mathrm{ALA}$ was recrystallized from cold dry methanol and dry ether; it had m.p. $147-149^{\circ}$, and contained $29 \cdot 5 \mu \mathrm{c} / \mathrm{m}$-mole.

ALA was administered intraperitoneally to rats and orally to human subjects by the methods described (Berlin et al. 1956). Estimations of ALA were carried out by both the picrate and acetoacetate methods of Shuster (1956).

Porphobilinogen. PBG was isolated by the method of Cookson \& Rimington (1954). Determination was by the modified method described (Berlin et al. 1956).

Porphyrins and stercobilin. Stercobilin and crude porphyrins were isolated from the faeces by the methods used by Gray \& Neuberger (1950) and by Gray, Neuberger \& Sneath (1950) respectively. After separation by partition between ether and $\mathrm{HCl}$ (Zeile \& Rau, 1937), coproporphyrin and protoporphyrin were estimated by measurement of the optical density at the peak of the Soret band in $0.1 \mathrm{~N}-\mathrm{HCl}$ (Jope \& O'Brien, 1945) and $2 \mathrm{~N}-\mathrm{HCl}$ (Bois, 1927) respectively. The crude porphyrin, which consisted almost entirely of protoporphyrin, was then esterified and purified chromatographically on $\mathrm{CaCO}_{3}$ by the method of Grinstein, Schwartz \& Watson (1945). Before assay of radioactivity, stercobilin was recrystallized as the hydrochloride from chloroformlight petroleum (boiling range $60-80^{\circ}$ ), and protoporphyrin was recrystallized as the methyl ester from chloroformmethanol.

Blood haemoglobin. This was determined by the method of Wong (1928).

\section{Apparatus and methods}

Animals. Albino rats of the National Institute for Medical Research strain were used. After injection of labelled ALA, they were kept either in ordinary metabolism cages or else in a special metabolism jar of the type illustrated in Fig. 1.

Collection of $\mathrm{CO}_{2}$ from rat breath. For collection of $\mathrm{CO}_{2}$ from the breath, a rat was placed in the metabolism jar (Fig. 1), and a brisk stream of air was drawn through the apparatus. Food and water were provided, and coprophagy was not observed.

Collection of $\mathrm{CO}_{2}$ from human breath and conversion into $\mathrm{BaCO}_{3}$. One end of a length of glass tubing $(1 \mathrm{~cm}$. bore) was worked in a flame so that a flange was formed at right angles to the axis, and of about $3.5 \mathrm{~cm}$. in diameter. The other end of the tube was connected, through a flutter valve followed by a large glass tap, to a meteorological balloon; a conventional Douglas bag was found to be too large, and could not easily be emptied quantitatively. Before giving a breath sample, the subject breathed into the balloon for about 5 min., breathing air in through the nose and expelling it through the glass tube, the flanged end of which fitted comfortably between the lips and the teeth. On each occasion, after a 5 min. practice period, the balloon was disconnected, rapidly emptied, reconnected, and a sample taken for precisely $1 \mathrm{~min}$. The balloon was subsequently emptied and the $\mathrm{CO}_{2}$ converted quantitatively into $\mathrm{BaCO}_{3}$ by the method of Berlin, Tolbert \& Lawrence (1951).

Blood ${ }^{14} \mathrm{C}$. In the experiment with a human subject, blood samples (10 ml.) were withdrawn from an arm vein into a sterile syringe containing heparin, and were immediately centrifuged in graduated tubes, and the haematocrit value was noted. For each sample, plasma $(0.50 \mathrm{ml}$.) and packed red cells $(0 \cdot 2-0 \cdot 4 \mathrm{~g}$. weighed accurately) were removed and dried in vacuo for combustion.

Total urinary and faecal ${ }^{14} \mathrm{C}$. A measured volume (2-3 ml.) of each urine sample was transferred to a $100 \mathrm{ml}$. conical flask having a ground glass joint, and was dried in a vacuum desiccator. Each faeces sample was weighed and homogenized; a small quantity (about $0.5 \mathrm{~g}$.) was weighed accurately in a tared conical flask and dried, and the dry weight was determined.

Combustion of total carbon to $\mathrm{CO}_{\mathbf{2}}$. Dried samples of blood, urine or faeces were combusted in the conical flasks with a

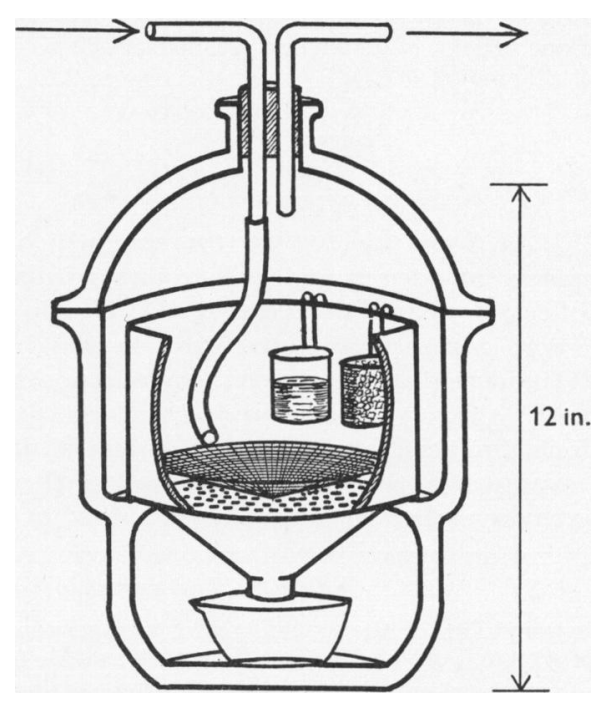

Fig. 1. Metabolism jar for collection of rat-breath $\mathrm{CO}_{2}$. The jar consisted of a small desiccator (internal diameter, 9 in.) containing a Büchner funnel (internal diameter, 8 in.) with the spout cut short. The exposed unglazed porcelain was coated with silicone grease to prevent loss of urine. A shallow cone of wire gauze or perforated zinc was placed inside the funnel to prevent elution of the faeces by the urine, the latter being collected in an evaporating dish. The exit tube was led into a $\mathrm{CO}_{2}$ trap (Berlin, Tolbert \& Lawrence, 1951) and thence to a water pump. 
chromic acid-sulphuric acid mixture (Van Slyke \& Folch, 1940); the $\mathrm{CO}_{2}$ evolved was collected and converted into $\mathrm{BaCO}_{3}$ by the method of Berlin et al. (1951).

\section{Assay of radioactivity}

The particular assay method used is indicated in the tables where the data are shown. Values obtained by the different methods were directly comparable, since figures agreeing within $3 \%$ were obtained when a sample of hippuric acid having $0 \cdot 1 \mu \mathrm{c} / \mathrm{mg}$. was assayed by all four methods.

Method A. The more radioactive samples (counting rate over three times the background rate) were counted on $0.3 \mathrm{~cm} .^{2}$ Perspex disks, with an end-window counter. When only 3-6.5 mg. of material was available, the observed counting rate was extrapolated from a calibration curve to obtain the 'infinite' thickness rate.

Method B: Certain $\mathrm{BaCO}_{3}$ samples were counted at 'infinite' thickness on $2 \mathrm{~cm} .{ }^{2}$ polythene disks.

Method C. Less active samples, in the form of $\mathrm{BaCO}_{3}$, were taken to the Radiation Laboratory, University of California, Berkeley, where determination of the radioactivity was kindly carried out for us by Dr Tolbert. The samples were converted into $\mathrm{CO}_{2}$ and counted in a $100 \mathrm{ml}$. ionization chamber operating at atmospheric pressure. In an ionization chamber of this size the sensitivity is $\mathbf{0 . 0 2}$ disintegration/min./mg. of $\mathrm{BaCO}_{3}$ (B. M. Tolbert \& Elton M. Baker, to be published; cf. Baker, Tolbert \& Marcus, 1955).

Method D. Haemin samples prepared from the blood of birds were converted into $\mathrm{CO}_{2}$ by dry combustion and the radioactivity was measured in a gas counter at the National Institute for Medical Research (Bradley, Holloway \& McFarlane, 1954). Combustion yielded $98-99 \%$ of the theoretical amount of $\mathrm{CO}_{2}$.

\section{RESULTS}

\section{Preliminary experiments with rats}

[1:4-14 $\left.\mathrm{C}_{2}\right] \mathrm{ALA}$ was injected into two rats, which were then placed at once in metabolism jars suitable for the collection of breath $\mathrm{CO}_{2}$ (Fig. 1). The doses of ALA were respectively lower (rat 1) and higher (rat 2) than the dose later given to a human subject.

Breath $\mathrm{CO}_{2}$ was collected continuously, in fractions, for the first $30 \mathrm{hr}$. After elapse of this time, samples were collected intermittently until the sixth day, when the animals were killed in order to isolate the blood haem. Very little radioactivity was found in the breath $\mathrm{CO}_{2}$ after the first day. In rat 1, which had the lower dose, relatively less of the radioactivity was excreted in the urine than in the breath and faeces. In rat 2 this situation was reversed. Both animals excreted altogether about two-thirds of the radioactivity. The results of this experiment are set out in Table 1.

The radioactivity found in the haemin prepared from the blood of the rats is shown in Table 2 . It may be seen that the small fraction of the administered ALA which is incorporated does not appear to vary with the dose. Additional data, previously obtained with necessarily very much

\section{Table 1. Excretion of radioactivity by rats which had received $\left[1: 4-{ }^{14} \mathrm{C}_{2}\right] A L A$}

All samples were counted as $\mathrm{BaCO}_{3}$ by method $C$, except the first three breath samples of rat 2 , which were counted by method $B$ (see Experimental section). Rat 1 received $0.0045 \mathrm{~m}$-mole of ALA/100 g., and rat $20.043 \mathrm{~m}$-mole of ALA/100 g. The total radioactivities administered were $0 \cdot 268$ and $2 \cdot 41 \mu \mathrm{c}$ respectively. A dash indicates that no urine or no faeces were produced in the period concerned.

\begin{tabular}{|c|c|c|c|c|}
\hline & \multirow{2}{*}{$\begin{array}{c}\text { Time } \\
\text { after } \\
\text { dose } \\
\text { (hr.) }\end{array}$} & \multicolumn{3}{|c|}{$\begin{array}{l}\text { Cumulative percentage of the } \\
\text { total radioactivity excreted }\end{array}$} \\
\hline & & $\begin{array}{l}\text { Breath } \\
\mathrm{CO}_{2}\end{array}$ & Faeces & Urine \\
\hline \multirow[t]{2}{*}{ Rat 1} & $\begin{array}{l}3 \\
6 \\
22 \cdot 5 \\
29 \\
51 \\
70 \cdot 5 \\
120\end{array}$ & $\begin{array}{l}11 \cdot 0 \\
13 \cdot 2 \\
16 \cdot 9 \\
17 \cdot 0 \\
17 \cdot 0 \\
17 \cdot 0 \\
17 \cdot 0\end{array}$ & $\begin{array}{c}\overline{0.2} \\
15.5 \\
\overline{17.4} \\
17.9 \\
18.9\end{array}$ & $\begin{array}{c}-\overline{21 \cdot 1} \\
24 \cdot 8 \\
\overline{25 \cdot 1} \\
25 \cdot 2 \\
25 \cdot 3\end{array}$ \\
\hline & & \multicolumn{3}{|c|}{$\begin{array}{l}\text { Total }{ }^{14} \mathrm{C} \text { excreted by rat } 1 \text { in } \\
5 \text { days }=61 \cdot 2 \%\end{array}$} \\
\hline Rat 2 & $\begin{array}{c}\mathbf{3 \cdot 5} \\
6 \cdot 3 \\
24 \\
51 \\
72 \\
120\end{array}$ & $\begin{array}{r}4 \cdot 6 \\
7 \cdot 8 \\
10 \cdot 9 \\
11 \cdot 3 \\
11 \cdot 5 \\
11 \cdot 9\end{array}$ & $\begin{array}{c}- \\
\overline{10 \cdot 3} \\
\overline{14.5} \\
14.8\end{array}$ & $\begin{array}{l}-\overline{34 \cdot 7} \\
37 \cdot 3 \\
37 \cdot 5 \\
37 \cdot 6 \\
37 \cdot 7\end{array}$ \\
\hline & & \multicolumn{3}{|c|}{$\begin{array}{l}\text { Total }{ }^{14} \mathrm{C} \text { excreted by rat } 2 \text { in } \\
5 \text { days }=64.4 \%\end{array}$} \\
\hline
\end{tabular}

Table 2. Incorporation of isotopic $A L A$ into haemoglobin haem

Rats were killed on the sixth day after intraperitoneal injection of isotopic ALA. The data from which the incorporation of $\left[{ }^{15} \mathrm{~N}\right] \mathrm{ALA}$ has been calculated have been taken from the previous paper (Berlin et al. 1956). For calculation of the percentage incorporation, the observed isotope contents of the haemin have been corrected for loss of $\frac{6}{16}$ of ${ }^{14} \mathrm{C}$ or $\frac{6}{8}$ of ${ }^{15} \mathrm{~N}$ which must have occurred during the conversion of PBG into protoporphyrin.* It was calculated that the rats contained the equivalent of $30 \mathrm{mg}$. of haemin $/ 100 \mathrm{~g}$. (see text).

\begin{tabular}{|c|c|c|c|c|}
\hline $\begin{array}{c}\text { Rat } \\
\text { (no.) }\end{array}$ & Compound injected & $\begin{array}{c}\text { Dose } \\
\text { (m-mole/100 g.) }\end{array}$ & Isotope content observed & $\begin{array}{l}\text { of the ALA } \\
\text { used for haem } \\
\text { synthesis }\end{array}$ \\
\hline $\begin{array}{l}1 \\
2 \\
17+18 \\
30+31\end{array}$ & $\begin{array}{l}{\left[1: 4-{ }^{14} \mathrm{C}_{2}\right] \text { ALA }} \\
{\left[1: 4-14 \mathrm{C}_{2}\right] \text { ALA }} \\
{\left[{ }^{15} \mathrm{~N}\right] \mathrm{ALA}} \\
{\left[{ }^{15} \mathrm{~N}\right] \mathrm{ALA}}\end{array}$ & $\begin{array}{l}0 \cdot 0045 \\
0 \cdot 043 \\
0 \cdot 20 \\
0 \cdot 50\end{array}$ & $\begin{array}{l}1.947 \times 10^{-3} \mu \mathrm{c} / \mathrm{m}-\text { mole } \\
1.956 \times 10^{-2} \mu \mathrm{c} / \mathrm{m}-\text { mole } \\
0.018 \text { atom } \% \text { excess } \\
0.045 \text { atom } \% \text { excess }\end{array}$ & $\begin{array}{l}0.11 \\
0 \cdot 12 \\
0.11 \\
0.11\end{array}$ \\
\hline
\end{tabular}

* $16{ }^{14} \mathrm{C}$ atoms or $8^{15} \mathrm{~N}$ atoms in 8 molecules of the isotopic ALA are required for producing one protohaem molecule; 6 carboxyl-14 $\mathrm{C}$ atoms or $4^{15} \mathrm{~N}$ atoms are eliminated in the process. 
larger doses of $\left[{ }^{15} \mathrm{~N}\right] A L A$, have been included. The total radioactivity incorporated into haem was calculated for a haem content equivalent to $30 \mathrm{mg}$. of haemin $/ 100 \mathrm{~g}$. This figure was calculated from the blood-haemoglobin concentration of $17 \cdot 1 \mathrm{~g} . / 100 \mathrm{ml}$., determined by the method described, assuming a blood volume of $4.6 \mathrm{ml}$./100 g. (Berlin, Huff, Van Dyke \& Hennessy, 1949).

\section{Experiments with cockerels}

It was considered possible that the different excretory system of birds, in particular the smaller volume of water lost, might cause an increased utilization of administered ALA for synthesis of haem by decreasing the amount lost in the urine compared with that lost in mammals. This was not found to be the case, since the amount of $\left[1: 4-{ }^{14} C_{2}\right]$ ALA incorporated into haem by a cockerel was approximately the same as in mammals, assuming,

Table 3. Incorporation of ALA or succinate into haem by cockerels

[1:4- $\left.{ }^{14} \mathrm{C}_{2}\right]$ Succinic acid and $\left[1: 4-{ }^{14} \mathrm{C}_{2}\right]$ ALA contained $32 \cdot 0$ and $29.5 \mu \mathrm{c} / \mathrm{m}$-mole respectively. Both compounds were injected intraperitoneally $(0.02 \mathrm{~m}-\mathrm{mole} / 100 \mathrm{~g}$. $)$ and the birds were killed after 6 days. It was assumed that the cockerels contained the same proportion of haem as rats (see text). The haemin radioactivity has been corrected for loss of ${ }^{14} \mathrm{C}$ (see Table 2), and was assayed by method $D$.

$\begin{array}{cccc}\text { Bird } & \text { Compound } & \begin{array}{c}\text { Corrected } \\ \text { haemin } \\ \text { radioactivity } \\ (\mu \mathrm{c} / \text { mole })\end{array} & \begin{array}{c}\text { Percentage of } \\ \text { the compound }\end{array} \\ \text { (no.) } & \begin{array}{c}\text { injected } \\ \text { synthesis }\end{array} \\ 19 & {\left[1: 4-{ }^{14} \mathrm{C}_{2}\right] \text { ALA }} & 12 \cdot 2 & 0.095 \\ 20 & {\left[1: 4-{ }^{14} \mathrm{C}_{2}\right] \text { succinic acid }} & 0.115 & 0.00083\end{array}$

in the absence of accurate data on the blood volume of birds, that the haem content/100 g. was the same as that of rats (Table 3). An equimolar dose of [1:4-14 $\left.\mathrm{C}_{2}\right]$ succinic acid, having a similar specific activity, was given to a second cockerel. In contrast to glycine (Neuberger \& Scott, 1953), incorporation of the labelled succinate into haem was over 100 times less than that of correspondingly labelled ALA (Table 3).

\section{Administration of $\left[1: 4-{ }^{14} \mathrm{C}_{2}\right] A L A$ to man}

A solution of $\left[1: 4-{ }^{14} \mathrm{C}_{2}\right]$ ALA (1.00 g. of the hydrochloride) was swallowed by one of us (J.J.S.) at 7.00 a.m., and no food was taken until midday, in order not to hinder the absorption. This dose was equivalent to $0.007 \mathrm{~m}-\mathrm{mole} / 100 \mathrm{~g}$. Frequent samples of blood, breath, urine and faeces were taken throughout the day, and afterwards daily for $84 \mathrm{hr}$. No method for re-isolation of ALA from urine was available at this time, so that the specific activity of the excreted ALA could not be determined. Urinary PBG, faecal porphyrins and stercobilin were isolated and estimated by the methods described.

The amounts, specific radioactivities and isotopic dilutions of the several compounds excreted and isolated are shown in Table 4. It can be seen that dilution of the newly formed PBG and protoporphyrin by endogenous material was marked, though not great. The significance of the constancy of the activity of the protoporphyrin isolated on 4 successive days is discussed below. In addition to protoporphyrin, small amounts of coproporphyrin I (about $0.5 \mathrm{mg}$. of the methyl ester, m.p. 218-220 were isolated from the daily faeces samples. The

\section{Table 4. Amounts and specific activities of compounds isolated}

[1:4-14 $\mathrm{C}_{2}$ ]ALA (1.001 g.; 0.0075 m-mole/100 g., having $\left.0.8111 \mu \mathrm{c} / \mathrm{m}-\mathrm{mole}\right)$ was taken orally by a man weighing $79 \cdot 4 \mathrm{~kg}$. Total radioactivity received was $4.85 \mu \mathrm{c}$. The radioactivity of the haemin was significant but very low $(0.0702 \pm 0.03$ disintegration/min./mg. of $\mathrm{BaCO}_{3}$ by method $C$ after combustion); for this reason the haemin activity could not be determined with the same precision as those of other compounds, which were assayed by method $A$. In the calculations required to obtain the figures in the last column, the observed activities (column 4) have been divided by the number of ALA residues in the compound concerned, the activities of tetrapyrrolic compounds having first been corrected for loss of ${ }^{14} \mathrm{C}$ (see Table 2).

\begin{tabular}{|c|c|c|c|c|}
\hline Compound & $\begin{array}{c}\text { Period over } \\
\text { which sample } \\
\text { was collected } \\
\text { (hr. after dose) }\end{array}$ & $\begin{array}{c}\text { Amount } \\
\text { excreted } \\
\text { (mg. of the } \\
\text { hydrochloride) }\end{array}$ & $\begin{array}{c}\text { Specific } \\
\text { activity } \\
(\mu \mathrm{C} / \mathrm{m}-\mathrm{mole})\end{array}$ & $\begin{array}{c}\text { Observed } \\
\text { specific activity } \\
\text { as percentage } \\
\text { of the maximum } \\
\text { value }\end{array}$ \\
\hline ALA & 0-24 & 319 & Not isolated & $?$ \\
\hline PBG & $0-8$ & $29 \cdot 4$ & $1 \cdot 27$ & $78 \cdot 1$ \\
\hline Protoporphyrin & $\begin{array}{r}0-12 \\
13-36 \\
37-60 \\
61-84\end{array}$ & $\begin{array}{r}4 \cdot 9 \\
12 \cdot 9 \\
3 \cdot 2 \\
4 \cdot 1\end{array}$ & $\begin{array}{l}2 \cdot 39 \\
2 \cdot 36 \\
2 \cdot 38 \\
2 \cdot 36\end{array}$ & $\begin{array}{l}\mathbf{5 9 \cdot 0} \\
\mathbf{5 8 \cdot 3} \\
\mathbf{5 8 \cdot 7} \\
\mathbf{5 8 \cdot 3}\end{array}$ \\
\hline Stercobilin & $\begin{array}{r}0-12 \\
13-36 \\
37-60 \\
61-84\end{array}$ & $\begin{array}{r}188 \\
212 \\
74 \\
277\end{array}$ & $\begin{array}{l}0 \cdot 0036 \\
0 \cdot 1200 \\
0 \cdot 1050 \\
0 \cdot 0459\end{array}$ & $\begin{array}{l}0 \cdot 1 \\
3 \cdot 0 \\
2 \cdot 6 \\
1 \cdot 1\end{array}$ \\
\hline Haemin & After 5 days & 一 & $2 \cdot 1 \times 10^{-4} \pm 43 \%$ & 0.005 \\
\hline
\end{tabular}


quantities available were insufficient for determination of the specific activity after purification. The rates of excretion of radioactivity in the various fractions, and in specific compounds, have been plotted in Figs. 2-4. The total radioactivity in any fraction (Table 5) is therefore equal to the integral after zero time of the corresponding curve in Figs. 2, 3 or 4. The percentage of the total radioactivity associated with each fraction is shown in Table 5. The haemoglobin concentration was found to be $17.0 \mathrm{~g} . / 100 \mathrm{ml}$. of blood, and the blood volume was taken to be $68.6 \mathrm{ml} . / \mathrm{kg}$. (Berlin, Lawrence \& Gartland, 1950). The total haemoglobin haem was therefore equivalent to $355 \mathrm{mg}$. of haemin/kg., and the total blood volume was 5.45 l., since the subject weighed $79.4 \mathrm{~kg}$. Although the urinary excretion of ALA roughly paralleled the total urine ${ }^{14} \mathrm{C}$ (Fig. 2), a substantial proportion of the urinary ${ }^{14} \mathrm{C}$, particularly that part excreted after $6 \mathrm{hr}$., has not been accounted for as specific compounds (Table 5). Although additional contributions may be expected from urea ${ }^{14} \mathrm{C}$ and $\mathrm{H}^{14} \mathrm{CO}_{3}{ }^{-}$ion, in view of the rate of ${ }^{14} \mathrm{C}$ excretion by the lungs (Fig. 3), it is likely that other, more specific metabolites of ALA were present. Similar considerations apply to the faecal ${ }^{14} \mathrm{C}$ (Fig. 4 and Table 5), except that the total faecal ${ }^{14} \mathrm{C}$ in the final period was entirely due to protoporphyrin and stercobilin.

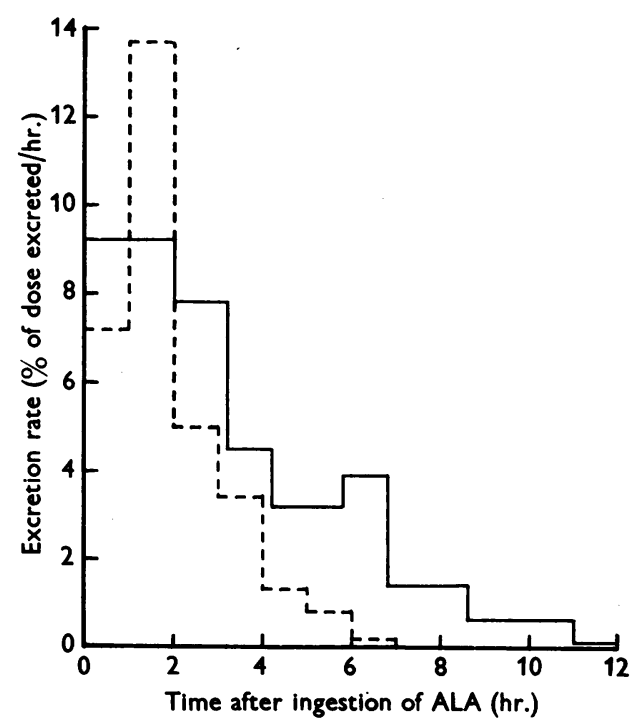

Fig. 2. Urinary-excretion rates of ALA (broken line) and of total ${ }^{14} \mathrm{C}$ (continuous line) by a human subject after ingestion of $\left[1: 4-{ }^{14} \mathrm{C}_{2}\right] A L A$. The subject (J.J.S.) received $0.0075 \mathrm{~m}$-mole of $\left[1: 4-{ }^{14} \mathrm{C}_{2}\right] \mathrm{ALA}(29.5 \mu \mathrm{c} / \mathrm{m}-\mathrm{mole}) / 100 \mathrm{~g}$. body weight. The data for ALA excretion were obtained subsequently with the same subject given an exactly similar dose of non-isotopic ALA. Total urinary ${ }^{14} \mathrm{C}$ was assayed by method $C$.
The appearance of ${ }^{14} \mathrm{C}$ in the blood was followed directly. Blood samples were taken at intervals, and the radioactivity of the packed red cells was measured separately from that of the plasma, in order to see whether ALA or a metabolite was actively taken up from the plasma by the red cells. The change in the activities in the red cells and in the plasma with time is shown in Fig. $5 a$, and the ratio of these activities is shown in Fig. $5 b$. At the peak of the red-cell curve in Fig. $5 a$, after $3 \cdot 3 \mathrm{hr}$., both the whole blood and the red cells contained the maximum activity observed: $\mathbf{1 4 . 8} \%$ of the total radioactivity administered was in the whole blood, and $11.2 \%$ was in the red cells. It is apparent from Fig. $5 b$ that an early component of the plasma ${ }^{14} \mathrm{C}$ is being actively taken up and partially retained by the red cells.

From the curve for plasma ${ }^{14} \mathrm{C}$ (Fig. 5a) the mean plasma ${ }^{14} \mathrm{C}$ concentrations during the periods of urine collection can be estimated. This permits calculation of mean plasma clearances of ${ }^{14} \mathrm{C}$ over the appropriate periods. Results of these calcula-

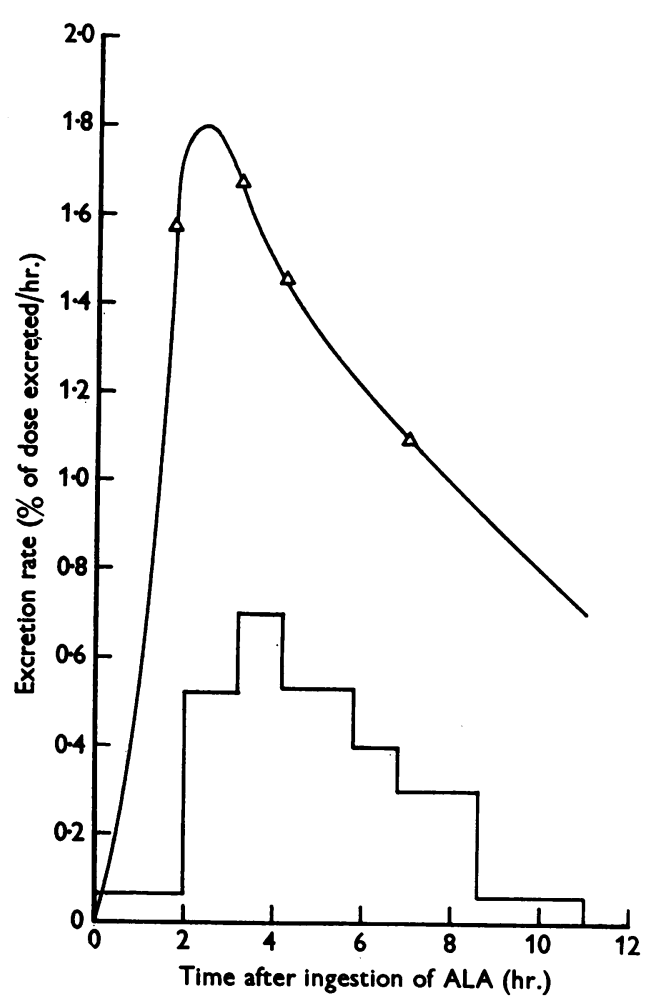

Fig. 3. Excretion rates of ${ }^{14} \mathrm{C}$ in the breath and in urinary $\mathrm{PBG}$, after ingestion of $\left[1: 4-{ }^{14} \mathrm{C}_{2}\right] \mathrm{ALA}$ by a human subject. Conditions as in Fig. 2. $\square, P B G{ }^{14} \mathrm{C}$ (assayed by method $A$ ); $\triangle$, breath ${ }^{14} \mathrm{CO}_{2}$ (assayed by method $C$ ). After $26 \mathrm{hr}$. the rate of excretion of ${ }^{14} \mathrm{C}$ in the breath was zero; this point is not shown in the figure. 
tions are given in Table 6, where also the concentrations of total ${ }^{14} \mathrm{C}$ and of $(\mathrm{ALA}+\mathrm{PBG}) \cdot{ }^{14} \mathrm{C}$ in the urine are compared. It may be seen that the clearance values fall into three groups, corresponding approximately to the periods of urinary excretion of ${ }^{14} \mathrm{C}$ derivable as follows: (1) mainly from ALA + PBG ; (2) from ALA + PBG + unknown compounds; (3) mainly from unknown compounds.

\section{Administration of $\left[{ }^{15} \mathrm{~N}\right] A L A$ to man}

In order to test whether a comparable dilution of newly formed PBG was obtained in a different subject, and at a different dose level, a further experiment was performed, with $\left[{ }^{15} \mathrm{~N}\right] A L A$. The hydrochloride (3.00 g., containing 0.999 atom \% of excess ${ }^{15} \mathrm{~N}$ ) was administered to a second male subject (K.D.G.), weighing $85.6 \mathrm{~kg}$; t the severe erythems which resulted from this large dose of ALA has been described (Berlin et al. 1956). The proportion of ALA excreted in the urine was $52.3 \%$, and PBG containing 0.944 atom $\%$ of excess ${ }^{15} \mathrm{~N}$ was isolated from the urine voided between 0 and $8 \mathrm{hr}$. (see Table 7).

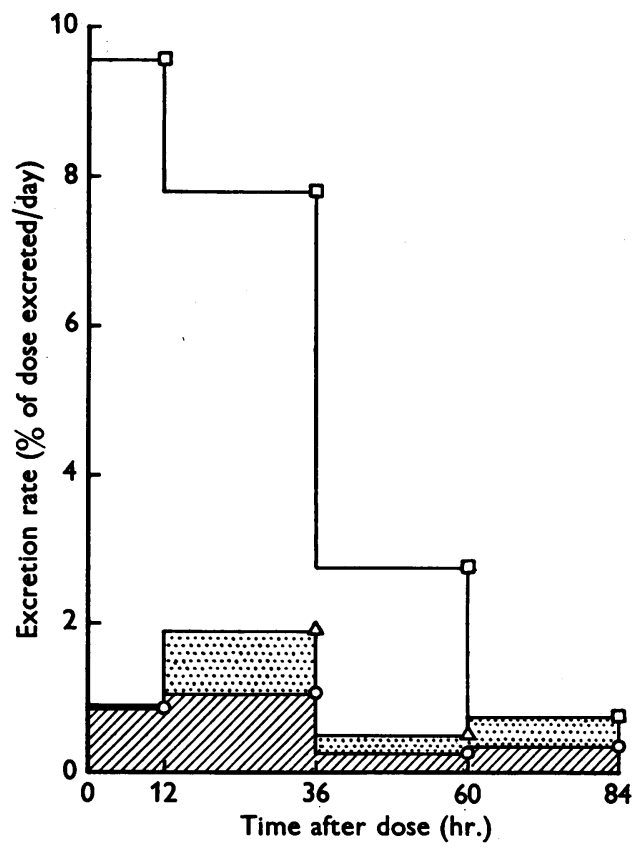

Fig. 4. Excretion rates of ${ }^{14} \mathrm{C}$ in the faeces, after ingestion of $\left[1: 4-{ }^{14} \mathrm{C}_{2}\right] \mathrm{ALA}$ by a human subject. Conditions as in Fig. 2. $\square$ (plain area), total faecal ${ }^{14} \mathrm{C}$ (assayed by method $C$ ); $\triangle$ (stippled area), protoporphyrin ${ }^{14} \mathrm{C}$; $\mathrm{O}$ (hatched area), stercobilin ${ }^{14} \mathrm{C}$ (both assayed by $\operatorname{method} A$ ).

\section{DISCUSSION}

It is apparent from the results presented here and in the previous paper (Berlin et al. 1956) that the general pattern of the metabolism of administered aminolaevulic acid is very similar in the rat (Table 1) and in man (Table 5); this similarity extends to birds, at least as judged on the basis of the degree of incorporation of aminolaevulic acid into haem (Tables 2 and 3). Quantitatively, the main features of aminolaevulic acid metabolism, based on the results in man, are a rapid excretion of unchanged material (about $30 \%$ ) and a transformation into other compounds, some of which (about $50 \%$ ) are excreted rapidly, while others (about $20 \%$ ) are still in the body after 4 days.

\section{Faecal radioactivity}

In man, the faecal radioactivity is believed to arise entirely from metabolized rather than from unabsorbed aminolaevulic acid, since similar fractions of the dose were recovered from the faeces of the rats, to which the dose had been administered parenterally. The small fraction of the faecal radioactivity accounted for has already been mentioned: it is possible that, had the isolation of

Table 5. Recovery of radioactivity after giving $\left[1: 4-{ }^{14} \mathrm{C}_{2}\right] A L A$ to man

The conditions of the experiment from which the follow. ing data are compiled have been summarized in Table 4. It was calculated that the subject contained the equivalent of $355 \mathrm{mg}$. of haemin $/ \mathrm{kg}$. (see text). Since the measurements of breath ${ }^{14} \mathrm{CO}_{2}$ were discontinuous, the total radioactivity excreted by this route was obtained by measuring the area from 0 to $24 \mathrm{hr}$. below the interpolated curve in Fig. 3. The value for the maximum radioactivity that can have been excreted as ALA was calculated from the amount of this compound excreted, by assuming that there had been no dilution by endogenous ALA; the minimum value was obtained by assuming that the dilution of the PBG was entirely due to endogenous ALA.

\begin{tabular}{|c|c|c|}
\hline \multirow[b]{2}{*}{ Fraction } & \multicolumn{2}{|c|}{$\begin{array}{l}\text { Percentage of } \\
\text { total radioactivity }\end{array}$} \\
\hline & $\begin{array}{l}\text { In the whole } \\
\text { fraction } \\
\text { after } 84 \mathrm{hr} .\end{array}$ & $\begin{array}{l}\text { In specific } \\
\text { compounds } \\
\text { isolated }\end{array}$ \\
\hline Breath $\mathrm{CO}_{2}$ & $14 \cdot 8$ & - \\
\hline $\begin{array}{l}\text { Whole urine } \\
\text { ALA } \\
\text { PBG } \\
\text { Unaccounted for }\end{array}$ & $\begin{array}{c}48 \cdot 6 \\
-\end{array}$ & $\begin{array}{c}-\overline{24 \cdot 5-31 \cdot 9} \\
3 \cdot 4 \\
13 \cdot 3-20 \cdot 7\end{array}$ \\
\hline $\begin{array}{l}\text { Whole faeces } \\
\text { Protoporphyrin } \\
\text { Stercobilin } \\
\text { Unaccounted for }\end{array}$ & $\frac{16 \cdot 1}{-}$ & $\begin{array}{r}\overrightarrow{2 \cdot 1} \\
1 \cdot 5 \\
12 \cdot 5\end{array}$ \\
\hline Blood haem & $0 \cdot 24$ & - \\
\hline Total & $79 \cdot 7$ & \\
\hline
\end{tabular}


porphyrins and bile pigment been carried out after previous sterilization of the alimentary tract with antibiotics, there might have been a greater recovery of ${ }^{14} \mathrm{C}$ in the compounds isolated. Watson (1938) reported that individual stercobilin excretion by a group of adults varied between 40 and $280 \mathrm{mg}$. day, whereas the daily bilirubin production by a $70 \mathrm{~kg}$. man should be about $250 \mathrm{mg}$. ; it is obvious therefore that the stercobilin excreted may represent only a small fraction of the bilirubin produced.

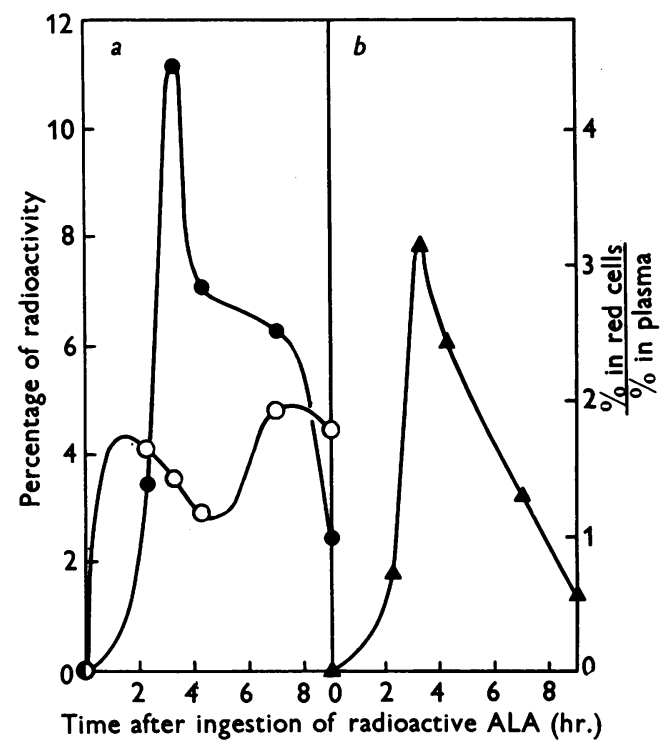

Fig. 5. (a) Variations of total red-cell and plasma ${ }^{14} \mathrm{C}$ with time after ingestion of [1:4- $\left.{ }^{14} \mathrm{C}_{2}\right] \mathrm{ALA}$ by a human subject. Conditions as in Fig. 2. The haemotocrit values were 50 for all blood samples taken during the period shown. Total ${ }^{14} \mathrm{C}$ was assayed by method $C$. The blood volume was taken to be 5.45 l. (see text). $O$, Red cells; $\bigcirc$, plasma. (b) Changes in the distribution of ${ }^{14} \mathrm{C}$ between red cells and plasma with time. Points on this curve are derived from the ratios of the values of ordinates in Fig. $5 a$.
The specific activity of the abnormally large quantities of protoporphyrin formed (totalling $25 \mathrm{mg}$.) remained approximately constant throughout the experiment. This suggests that all the protoporphyrin was formed at about the same time, and that an enterohepatic circulation caused the distribution of this material over the faeces produced during the subsequent 3 days. Enterohepatic circulation of naturally occurring porphyrins does not appear to have been described before, though Rothemund, McNary \& Inman (1934) and Rothemund (1935) have detected phylloerythrin and phylloporphyrin in ox bile. The presence of naturally occurring porphyrins in human bile is well recognized, but evidence that they are reabsorbed has hitherto been lacking. In view of the constant radioactivity of the protoporphyrin found in the present study, either this compound, after reabsorption into the portal blood, must have failed to equilibrate with the protoporphyrin (if any) being synthesized normally by the liver before re-excretion into the bile took place, or else free protoporphyrin is not a normal intermediate in the hepatic formation of haem proteins such as catalase. This latter interpretation is preferred, since liver cells are known to be extremely permeable to most small molecules. That aminolaevulic acid gives rise to porphyrins in vivo has also been demonstrated without the use of isotopes by cannulation of the bile duct of a rat after parenteral injection of aminolaevulic acid (Scott, 1955). As in the present experiments, only traces of coproporphyrin, but large quantities of protoporphyrin, were formed. It is not possible to decide from the data given here whether the porphyrin excreted was formed in the liver or extrahepatically. In view of the photosensitivity of human subjects given ALA (Berlin et al. 1956) it seems likely that there were porphyrins present peripherally; recently it has been found that porphyrins are present in the skin of rats after injection of aminolaevulic acid intra-

\section{Table 6. Plasma clearance of radioactivity}

Values of plasma clearance of ${ }^{14} \mathrm{C}$ have been calculated for each period of urine collection during the human experiment with [1:4-14 $\left.\mathrm{C}_{2}\right] \mathrm{ALA}$ (for details see Table 4 and Fig. 2). The clearance is given by $U \times V / P$, where $V$ is the rate of urine flow, and $U, P$ are the concentrations of ${ }^{14} \mathrm{C}$ in urine and plasma respectively. The mean plasma concentrations for the appropriate period of urine collection have been interpolated from the measurements shown in Fig. 5a, assuming a plasma volume of $2.73 \mathrm{l}$. In calculation of the values shown in the fourth column, it has been supposed that the ALA-14 $\mathrm{C}$ was not diluted, and that PBG had the activity shown in Table 4 ; these suppositions are not entirely correct since the concentration of (ALA + PBG) ${ }^{14} \mathrm{C}$ is apparently greater than $U$ in the first period.

\begin{tabular}{|c|c|c|c|c|c|}
\hline $\begin{array}{l}\text { Period } \\
\text { (hr.) }\end{array}$ & $\underset{(\mathrm{ml} . / \mathrm{min} .)}{V}$ & $\begin{array}{c}U \\
\text { (\% of dose/ml.) }\end{array}$ & $\begin{array}{c}\text { Urinary } \\
(\mathrm{ALA}+\mathrm{PBG}){ }^{14} \mathrm{C} \\
(\% \text { of dose } / \mathrm{ml} .)\end{array}$ & $\begin{array}{c}10^{3} P \\
\text { (\% of dose } / \mathrm{ml} . \text { ) }\end{array}$ & $\begin{array}{c}{ }^{14} \mathrm{C} \text { clearance } \\
\text { (ml. plasma/min.) }\end{array}$ \\
\hline $\begin{array}{l}0-2 \\
2-3 \cdot 17 \\
3 \cdot 17-4 \cdot 17 \\
4 \cdot 17-5 \cdot 83 \\
5 \cdot 83-6 \cdot 83 \\
6 \cdot 83-8 \cdot 58\end{array}$ & $\begin{array}{l}1 \cdot 22 \\
1 \cdot 36 \\
2 \cdot 48 \\
1 \cdot 05 \\
7 \cdot 56 \\
1 \cdot 31\end{array}$ & $\begin{array}{l}0.125 \\
0.096 \\
0.045 \\
0.051 \\
0.009 \\
0.018\end{array}$ & $\begin{array}{l}0 \cdot 144 \\
0.068 \\
0.033 \\
0.018 \\
0.002 \\
0.003\end{array}$ & $\begin{array}{l}1 \cdot 43 \\
1 \cdot 41 \\
1 \cdot 21 \\
1.34 \\
1 \cdot 69 \\
1 \cdot 72\end{array}$ & $\begin{array}{r}106 \\
93 \\
92 \\
40 \\
40 \\
14\end{array}$ \\
\hline
\end{tabular}


peritoneally, particularly if the animals are irradiated (Jarrett, Rimington \& Willoughby, 1956). It seems possible therefore that there was at least some extrahepatic synthesis of protoporphyrin from aminolaevulic acid, unless the porphyrin was incompletely excreted by the liver.

The rapid appearance of radioactivity in the stercobilin, considerably higher than in the circulating haem, is in agreement with previous findings that a small fraction of labelled glycine is converted rapidly into bile pigment by normal subjects (London, West, Shemin \& Rittenberg, 1950; Gray et al. 1950). The prolonged excretion of radioactive stercobilin was to be expected from the known enterohepatic circulation of this compound (McMaster \& Elman, 1925).

\section{Origin of the radioactive carbon dioxide}

In both rats and in the human subject a considerable amount (about $15 \%$ ) of the radioactivity from [1:4-14 $\mathrm{C}_{2}$ ]aminolaevulic acid was lost in the breath. Two possible origins of this ${ }^{14} \mathrm{CO}_{2}$ will be considered. In the conversion of the side chains of porphobilinogen into those of protoporphyrin, $\frac{6}{16}$ of the labelled carbon atoms of the original aminolaevulic acid must be lost as $\mathrm{CO}_{2}$, as are those of similarly labelled succinic acid (Shemin \& Wittenberg, 1951). Were all the breath ${ }^{14} \mathrm{CO}_{2}$ to have arisen in this way, it would require over $40 \%$ of the aminolaevulic acid to have been converted into protoporphyrin, haem or derived compounds such as stercobilin; and this figure does not allow for ${ }^{14} \mathrm{CO}_{2}$ so liberated but not excreted by the lungs. The sum of the radioactivity in the excreted tetrapyrroles and in haem was only $4 \%$ of the radioactivity given (Table 5). However, the sum of this radioactivity and that unaccounted for in the urine and faeces lies between 33 and $40 \%$. If the radioactivity unaccounted for were due to the presence of protoporphyrin catabolites, it would indicate that the breath ${ }^{14} \mathrm{CO}_{2}$ had resulted from protoporphyrin synthesis. An alternative origin is from degradation of the aminolaevulic acid to $\alpha$ oxoglutarate or succinate (cf. Shemin \& Russell, 1953), when a rapid release of ${ }^{14} \mathrm{CO}_{2}$ would be expected from oxidation of these compounds in the tricarboxylic acid cycle. Consideration solely of the percentage of the dose involved cannot distinguish between these alternative processes until components of the non-specific fraction of faecal and urinary ${ }^{14} \mathrm{C}$ have been identified. A similar ambiguity was noted when the mode of origin of isotopic ammonia from $\left[{ }^{15} \mathrm{~N}\right]$ aminolaevulic acid was discussed (Berlin et al. 1956).

Consideration of the times of appearance of the several radioactive compounds is more indicative. It may be seen in Fig. 3 that the peak of ${ }^{14} \mathrm{C}$ liberation precedes that of excretion of radioactive porphobilinogen in the urine. The peak of ${ }^{14} \mathrm{CO}_{2}$ liberation in porphyrin synthesis was therefore still later; it has in fact been shown that the peak of excretion of porphobilinogen in the urine precedes the peak of protoporphyrin excretion in the bile, after aminolaevulic acid has been given to rats (Scott, 1955). It is therefore concluded that the larger part of the breath ${ }^{14} \mathrm{CO}_{2}$ arose from oxidative degradation; this would accordingly represent the extent to which the aminolaevulic acid took part in any series of reactions such as the cycle proposed by Shemin \& Russell (1953). The total amount of administered aminolaevulic acid converted into protoporphyrin and derivatives should be proportional to the difference between the total pulmonary ${ }^{14} \mathrm{C}$ excretions after $\left[1: 4-{ }^{14} \mathrm{C}_{2}\right]$ and [2:3-14 $\mathrm{C}_{2}$ ]aminolaevulic acid respectively have been given, since ${ }^{14} \mathrm{CO}_{2}$ should not be lost from the latter compound during conversion into protoporphyrin.

\section{Significance of the changes in the radioactivity of the blood}

The plasma ${ }^{14} \mathrm{C}$ rose rapidly during the first $2 \mathrm{hr}$. and did not change greatly for the remainder of the experimental period of $9 \mathrm{hr}$. (Fig. 5a). The urinary ${ }^{14} \mathrm{C}$, on the other hand, decreased sharply and continuously after the first $2 \mathrm{hr}$. period. In order to compare radioactivities in plasma and urine respectively, plasma clearance values for ${ }^{14} \mathrm{C}$ were calculated (Table 6), and ${ }^{14} \mathrm{C}$ was thus treated as if it were present in one substance only. The ${ }^{14} \mathrm{C}$ clearance values during the first $4 \mathrm{hr}$. were close to the average inulin clearance value of $94 \mathrm{ml}$. $/ \mathrm{min}$. for adult man (Walser, Davidson \& Orloff, 1955). If the unlikely possibility is neglected that the first three observed figures are the fortuitous result of the presence in plasma of one substance which was actively secreted by the tubules while another substance was filtered and partially reabsorbed, it must be concluded that most of the radioactive material present in plasma during the first $4 \mathrm{hr}$. consisted of a substance or substances removed by glomerular filtration and not reabsorbed. Practically the whole of the radioactivity of the urine for the first $2 \mathbf{h r}$. period was due to aminolaevulic acid, whereas for the third and fourth hours this compound accounted for two-thirds and half respectively of the urinary radioactivity. It is therefore concluded that the changes in radioactivity in plasma and urine during the first $3 \mathrm{hr}$. represent largely the absorption of aminolaevulic acid from the gut and its excretion by the kidney through glomerular filtration, no appreciable reabsorption by the tubules taking place. However, during the third hour porphobilinogen was excreted in significant quantities; Goldberg \& Rimington (1954) have shown that this substance is eliminated only by glomerular filtration and is not reabsorbed or excreted by the tubules. A small amount of the aminolaevulic acid (2-3\%, 
Fig. 3) was degraded in the first 2-3 hr., yielding carbon dioxide which appeared in the breath. It is evident from the data of Stadie \& O'Brien (1937) that approximately $8 \%$ of the total blood $\mathrm{CO}_{2}$ is removed every minute by the lungs; ${ }^{14} \mathrm{CO}_{2}$ produced will accordingly be lost from the blood rapidly. It may be calculated that not more than $10 \%$ of the radioactivity of the plasma at $3 \mathrm{hr}$. can have been due to ${ }^{14} \mathrm{CO}_{2}$, assuming that the breath $\mathrm{CO}_{2}$ collected at this time was representative of the $\mathrm{CO}_{2}$ remaining in the blood. There may have been other radioactive substances present in the blood during the first 2-3 hr., but their concentration is likely to have been small compared with that of aminolaevulic acid.

The red-cell ${ }^{14} \mathrm{C}$ increased up to the end of the third hour, fell sharply in the fourth hour, rather slowly in the subsequent $3 \mathrm{hr}$. and then again rapidly (Fig. 5a). The shape of this curve, considered in conjunction with the changes in plasma ${ }^{14} \mathrm{C}$ and urinary excretion of aminolaevulic acid and porphobilinogen, suggests that aminolaevulic acid entered the red cells, but was there converted into other compounds $(Z)$. The hypothetical $Z$ is believed to have diffused out of the red cell in significant quantities after the third or fourth hour, then to contribute to the secondary rise in plasma ${ }^{14} \mathrm{C}$ (Fig. 5a), and also to the radioactivity of the urine in the later part of the experiment.

This later period (hours 4-11) was characterized by the following: (a) the urine ${ }^{14} \mathrm{C}$ was diminishing, but only a small part of it could be accounted for by aminolaevulic acid and porphobilinogen; $(b)$ the plasma ${ }^{14} \mathrm{C}$ remained high and thus the clearance values were steadily diminishing; (c) the breath ${ }^{14} \mathrm{CO}_{2}$ was decreasing. It would seem that during this period the plasma ${ }^{14} \mathrm{C}$ was due to substances including $Z$, which are metabolites of aminolaevulic acid. These substances were excreted partly in the urine, by a mechanism involving partial reabsorption or incomplete filtration; they may also have been excreted by other routes such as through the liver into the bile.

\section{Significance of the isotope dilutions}

Dilution of an administered labelled compound, or of its transformation products, by mixing with endogenous material can arise in two ways. First, there will be dilution if there is a measurable instantaneous concentration of endogenous material; secondly, there will also be dilution if there is a rapid endogenous production and simultaneous transformation of the appropriate compounds without measurable quantities of any but the final product ever accumulating. During active metabolism, therefore, the magnitude of the dilution will be a function partially of the length of time the system is in contact with the administered material.
When the specific activities of the compounds isolated in the first human experiment are compared (Table 4), it is clear that some mixing with endogenous material has occurred. It is not possible to obtain absolute values for the total endogenous materials without knowing how much of the dose actually mixed with these materials before being excreted or, alternatively, how much of the dose was converted into any compound under consideration. It may, however, be concluded that $22 \%$ of the porphobilinogen and over $40 \%$ of the protoporphyrin isolated had an endogenous origin. The fact that these two figures are different cannot be taken to indicate that there was equilibration with a reservoir of the intermediates between porphobilinogen and protoporphyrin, since it is not known that the two compounds were formed within the same period. It is certain only that there was mixing of some fraction of the dose with endogenous aminolaevulic acid or porphobilinogen or both.

It is reasonable to suppose that the time during which the labelled aminolaevulic acid was being incorporated into haemoglobin haem was not greatly different from the time during which it was being excreted either as such or after conversion into porphobilinogen. This time was about $8 \mathrm{hr}$. (Figs. 2, 3), during which $\frac{1}{360}$ of the total haem was renewed, assuming a mean red-cell life of 120 days. From the known total radioactivity in the haemoglobin haem it may accordingly be calculated that, had this labelled haem been incorporated during $8 \mathrm{hr}$, the mean specific activity of the aminolaevulic acid used would have been only $2 \%$ of the initial activity. It may be concluded that the labelled porphobilinogen, protoporphyrin and stercobilin isolated were not made in the haemopoietic tissues, where utilization of the administered material was evidently slight. The constancy of the proportion of the isotopic aminolaevulic acid incorporated into haemoglobin haem (Tables 2 and 3), in contrast to the increasing proportion of porphobilinogen excreted as the dose is increased (Berlin et al. 1956), suggests that there is a rate-limiting step associated with the utilization of aminolaevulic acid by the erythroblasts.

The data presented here (Table 3) and in the previous paper (Berlin et al. 1956; Table 1) show that glycine and succinic acid, the co-equal precursors of aminolaevulic acid, are incorporated into haem 7 times more and 100 times less respectively than an equivalent dose of aminolaevulic acid. The explanation of this must lie primarily in the different rates at which these compounds are metabolized and excreted after administration, but the possibility that erythroblasts are less permeable to aminolaevulic acid than to glycine cannot be excluded. 


\section{Table 7. Standard Dilution Capacities of subjects given isotopic aminolaevulic acid}

For definition of s.D.c. and other symbols, see equations (1) and (3). J.J.S. received [1:4-14 $\left.\mathrm{C}_{2}\right] \mathrm{ALA}$; K.D.G. received $\left[{ }^{15} \mathrm{~N}\right] \mathrm{ALA}$. With both subjects the urinary excretion of ALA was complete in $8 \mathrm{hr}$.

\begin{tabular}{|c|c|c|c|c|c|c|}
\hline Subject & $\begin{array}{c}Q \\
\text { (m-mole/kg.) }\end{array}$ & $C_{Q}$ & $\begin{array}{c}P \\
\text { within } 8 \mathrm{hr} .\end{array}$ & $C$ & $\begin{array}{l}\text { Observed } \\
\text { dilution } \\
\text { capacity }\end{array}$ & $\begin{array}{c}\text { S.D.c. } \\
(\mu \text { moles of } \\
\text { ALA/kg./day) }\end{array}$ \\
\hline J.J.S. & 0.075 & $\begin{array}{c}0.811 \\
(\mu \mathrm{c} / \mathrm{m}-\mathrm{mole})\end{array}$ & $4 \cdot 20$ & $\begin{array}{c}0 \cdot 634 \\
(\mu \mathrm{c} / \mathrm{m}-\mathrm{mole})\end{array}$ & 63 & 55 \\
\hline K.D.G. & 0.211 & $\begin{array}{c}0.999 \\
(\% \text { excess })\end{array}$ & $6 \cdot 48$ & $\begin{array}{c}0.944 \\
(\% \text { excess })\end{array}$ & $36 \cdot 7$ & 50 \\
\hline
\end{tabular}

In order to compare the dilutions in the excreted porphobilinogen isolated after administering isotopic aminolaevulic acid to human subjects, an arbitrary measure has been employed. This measure, termed the 'dilution capacity', is the rate of production of aminolaevulic acid which would be necessary to cause the mean dilution observed in the urinary porphobilinogen, if all the aminolaevulic acid given mixed with this endogenous material over a period of $8 \mathrm{hr}$., the period within which excretion of aminolaevulic acid and porphobilinogen is virtually complete. The dilution capacity is measured in $\mu$ moles of ALA $/ \mathrm{kg}$. day, and is defined by the following equation (cf. Arnstein \& Neuberger, 1951):

$$
\text { Dilution capacity }=\frac{24}{8} Q\left(C_{Q} / C-1\right) \text {, }
$$

where $Q$ is the dose of aminolaevulic acid (m-moles/ kg.), $C_{Q}$ is the initial isotope content and $C$ is the subsequent isotope content of the aminolaevulic acid used for synthesis of the porphobilinogen isolated from urine voided between 0 and $8 \mathrm{hr}$. As defined by equation (1), however, the dilution capacity in this and similar cases is not independent of the size of the dose where this is sufficiently large to increase the cellular concentration for a limited period, thereby increasing the degree of saturation of enzymes concerned in the transformations. The fraction of a dose of aminolaevulic acid transformed into porphobilinogen increases steadily with the dose (Berlin et al. 1956). Therefore, if the dose is increased, a larger fraction must mix with endogenous material at the sites of porphobilinogen production, causing a smaller value for the dilution capacity. In order to diminish this variability, a 'Standard Dilution Capacity' (s.D.c.) is defined (equations 2 and 3 ) as the value of the dilution capacity which would be expected if $4.8 \%$ of the dose was excreted in the form of porphobilinogen (this is the proportion usually excreted within $8 \mathrm{hr}$. when about $1 \mathrm{~g}$. of aminolaevulic acid is given orally to a $70 \mathrm{~kg}$. adult).

$$
\text { s.D.c. }=\frac{\% \text { of dose as urinary } \mathrm{PBG} \text { in } 8 \mathrm{hr} \text {. }}{4 \cdot 8 \times \text { dilution capacity. }}
$$

Combining with equation (1), this may be rewritten

$$
\text { S.D.c. }=0 \cdot 625 P \cdot Q\left(C_{Q} / C-1\right) \text {, }
$$

where $P$ is the observed percentage transformation into urinary porphobilinogen in $8 \mathrm{hr}$. The s.D.c. has only relative significance: it is only indirectly related to the true rate of extramedullary aminolaevulic acid production.

Results from experiments summarized above, in which isotopic aminolaevulic acid, differently labelled, was given at different dose levels to two male subjects, may now be compared (Table 7). In spite of the many possible variables for which no allowance can yet be made, the two s.D.c. values are found to agree quite closely. Further, any substantial departure from these values for the s.D.c. might be expected to provide evidence for and a measure of an abnormality in the rate of extramedullary aminolaevulic acid synthesis or of porphobilinogen utilization; such has indeed proved to be the case in acute porphyria (Neuberger, Scott \& Gray, 1954) and in photosensitive porphyrias (Scott \& Gray, to be published). The similarity of the S.D.c., as determined by use of $\left[1: 4-{ }^{14} \mathrm{C}_{2}\right]$ aminolaevulic acid, to that determined by the use of the ${ }^{15} \mathrm{~N}$-labelled compound indicates that it is unlikely that there is any extensive reversible deamination of aminolaevulic acid in normal man.

\section{SUMMARY}

1. $\left[1: 4-{ }^{14} \mathrm{C}_{2}\right]$ Aminolaevulic acid $\left({ }^{14} \mathrm{C}-\mathrm{ALA}\right)$ was administered parenterally to rats and cockerels and orally to a human subject. A similar proportion of the ${ }^{14} \mathrm{C}$ given was incorporated into haemoglobin haem by all three groups, regardless of the size of the dose of ALA, whereas incorporation of $\left[1: 4-{ }^{14} \mathrm{C}_{2}\right]$ succinic acid by cockerels was over 100 times less.

2. Administration of ${ }^{14} \mathrm{C}-\mathrm{ALA}$ was followed by rapid elimination of ${ }^{14} \mathrm{C}$ in breath, urine and faeces, one-fifth to one-third being retained after 3 days. General findings concerning the elimination and metabolism of ALA, based on previous results using $\left[{ }^{15} \mathrm{~N}\right] A L A$, were confirmed and extended. ALA is believed to be eliminated in the urine by renal filtration only.

3. This and subsequent paragraphs relate to data obtained from human experiments. Approximately two-thirds of the urine ${ }^{14} \mathrm{C}$, but only onequarter of the faecal ${ }^{14} \mathrm{C}$, was present in identified compounds. 
4. Radioactive porphobilinogen (PBG), protoporphyrin, stercobilin and haem were isolated and the specific activities compared. It is concluded that, of these compounds, the first three, which all had a relatively high specific radioactivity, had been synthesized outside the haemopoietic system. All four had undergone dilution by endogenous material.

5. Evidence has been obtained for an enterohepatic circulation of protoporphyrin in man. Large quantities of this compound, having constant radioactivity, were isolated from the faeces voided during 4 days after ${ }^{14} \mathrm{C}$-ALA had been given.

6. The peak of pulmonary ${ }^{14} \mathrm{C}$ excretion preceded by $\mathrm{l} \mathrm{hr}$. the peak of urinary excretion of radioactive PBG. The greater part of the breath ${ }^{14} \mathrm{CO}_{2}$ is therefore believed to have arisen from degradation of ${ }^{14} \mathrm{C}$-ALA, the remainder having resulted from conversion of this compound into protoporphyrin and derivatives.

7. The radioactivities of the red cells and plasma were measured separately at intervals after ingestion of ${ }^{14} \mathrm{C}$-ALA. The resulting data suggest that ALA was absorbed from the plasma by the red cells and there converted into other compounds, excreted in the urine more slowly than ALA or PBG. Factors influencing the blood ${ }^{14} \mathrm{C}$ levels are discussed.

8. A 'Standard Dilution Capacity' (s.D.c.) is defined, which permits comparison of the relative rates of extramedullary production of ALA in different individuals. Similar s.D.c. values were obtained with two normal human subjects given $\left[{ }^{15} \mathrm{~N}\right]$ - and $\left[1: 4-{ }^{14} \mathrm{C}_{2}\right]-A L A$ respectively.

We are grateful to Dr B. M. Tolbert, Radiation Laboratory, University of California, Berkeley, and to Mr R. C. Holloway at this Institute for gas-counting of ${ }^{14} \mathrm{CO}_{2}$, to $\mathrm{Mr}$ G. Dickinson at this Institute for measurement of ${ }^{15} \mathrm{~N}$, and to Professor C. H. Gray and Dr D. C. Nicholson, Department of Chemical Pathology, King's College Hospital, London, for isolation of faecal tetrapyrroles. We also wish to thank the subjects K.D.G. and B.A.A. for their cooperation, and Mr F. Grover, Mrs Betty Higginson, Mr C. Hill and Mr B. Wright for technical assistance.

\section{REFERENCES}

Arnstein, H. R. V. \& Neuberger, A. (1951). Biochem. J. 50, 154.

Baker, Elton M., Tolbert, B. M. \& Marcus, M. (1955). Proc. Soc. exp. Biol., N.Y., 88, 383.

Berlin, N. I., Gray, C. H., Neuberger, A. \& Scott, J. J. (1954). Biochem. J. 58, xxx.
Berlin, N. I., Huff, R. L., Van Dyke, D. C. \& Hennessy, T. (1949). Proc. Soc. exp. Biol., N.Y., 71, 176.

Berlin, N. I., Lawrence, J. H. \& Gartland, J. (1950). J. Lab. clin. Med. 36, 435.

Berlin, N. I., Neuberger, A. \& Scott, J. J. (1954). Abstr. 5th Int. Congr. Haemat., Paris, p. 279.

Berlin, N. I., Neuberger, A. \& Scott, J. J. (1956). Biochem. J. 64, 80.

Berlin, N. I., Tolbert, B. M. \& Lawrence, J. H. (1951). J. clin. Invest. 30, 73.

Bois, E. (1927). Recherches Spectrochimiques sur quelques Porphyrines Animales. Dissertation: Fribourg, Switzerland. Quoted by Lemberg, R. \& Legge, J. W. (1949). Haematin Compounds and Bile Pigments, p. 76. London: Interscience.

Bradley, J. E. S., Holloway, R. C. \& McFarlane, A. S. (1954). Biochem. J. 57, 192.

Cookson, G. H. \& Rimington, C. (1954). Biochem. J. 57, 476. Goldberg, A. \& Rimington, C. (1954). Lancet, 2, 172.

Gray, C. H. \& Neuberger, A. (1950). Biochem. J. 47, 81.

Gray, C. H., Neuberger, A. \& Sneath, P. H. A. (1950). Biochem. J. 47, 87.

Grinstein, M., Schwartz, S. \& Watson, C. J. (1945). J. biol. Chem. 157, 323.

Jarrett, A., Rimington, C. \& Willoughby, D. A. (1956). Lancet 1, 125.

Jope, E. M. \& O'Brien, J. R. P. (1945). Biochem. J. 39, 239.

London, I. M., West, R., Shemin, D. \& Rittenberg, D. (1950). J. biol. Chem. 184, 351.

McMaster, P. D. \& Elman, R. (1925). J. exp. Med. 41, 513, 719.

Neuberger, A. (1955). Rep. 3rd Int. Congr. Biochem., Brussels (in the Press).

Neuberger, A. \& Scott, J. J. (1953). Nature, Lond., 172, 1093.

Neuberger, A. \& Scott, J. J. (1954). J. chem. Soc. p. 1820.

Neuberger, A., Scott, J. J. \& Gray, C. H. (1954). Biochem. J. 58, xli.

Rothemund, P. (1935). J. Amer. chem. Soc. 57, 2179.

Rothemund, P., McNary, R. A. \& Inman, O. L. (1934). J. Amer. chem. Soc. 56, 2400.

Scott, J. J. (1955). The Biosynthesis of Porphyrins and Porphyrin Metabolism, Ciba Foundation Symp., p. 43. London: Churchill.

Shemin, D. \& Russell, C. S. (1953). J. Amer. chem. Soc. 75, 4873.

Shemin, D. \& Wittenberg, J. (1951). J. biol. Chem. 192, 315.

Shuster, L. (1956). Biochem. J. 64, 101.

Stadie, W. C. \& O'Brien, H. (1937). J. biol. Chem. 117, 439.

Van Slyke, D. D. \& Folch, J. (1940). J.biol.Chem. 136, 509.

Walser, M., Davidson, D. G. \& Orloff, J. (1955). J. clin. Invest. 34, 1520.

Watson, C. J. (1938). In Downey's Handbook of Haematology, vol. 4, p. 2447. New York: Hoeber.

Wong, S. Y. (1928). J. biol. Chem. 77, 409.

Zeile, K. \& Rau, B. (1937). Hoppe-Seyl. Z. 250, 197. 